\title{
Dose-Dependent Reduced Haloperidol/Haloperidol Ratios in Schizophrenic Patients
}

\author{
WenrHo Chang, Hai-Gwo Hwu, Hsien-Yuan Lane, Shih-Ku Lin, Teng-Yi Chen, \\ Horng Chen, Hae-Lang Wei, Wen-Long Lin, and Hsin-Nan Lin
}

Received December 14, 1990; revised version received May 2, 1991; accepted August 8, 1991.

\begin{abstract}
Plasma haloperidol (HAL) and reduced HAL (RHAL) concentrations were measured in 113 Chinese schizophrenic patients. Daily doses of HAL ranged from 8 to $65 \mathrm{mg}$. Samples were obtained under steady-state conditions and drawn 10-12 hours after the bedtime dose and before the morning dose. In all, 313 blood samples were collected. Multiple samples were obtained at the same doses in 63 patients and at two or three different doses in 31 patients. HAL and RHAL concentrations were assayed by high performance liquid chromatography. Interpatient variation in plasma HAL levels at a given dosage was up to sixfold. However, there was a high positive correlation between plasma levels and daily dosages with the equation of HAL plasma level $(\mathrm{ng} / \mathrm{ml})=0.88 \times$ dosage $(\mathrm{mg} / \mathrm{day})-0.56$ or $46.0 \times$ dosage $(\mathrm{mg} / \mathrm{day} / \mathrm{kg})+0.28$. The expected values are about $15-55 \%$ higher than those obtained from non-Chinese patients as reported in the literature. The RHAL/HAL ratios were dose-dependent. The greater the dose used, the higher the ratio. An upper therapeutic limit of plasma HAL level is suggested to be $25 \mathrm{ng} / \mathrm{ml}$, which can be achieved at dosages about $30 \mathrm{mg} /$ day in most Chinese patients. Based upon the dose-dependent increase in RHAL/HAL ratios, the importance of RHAL in determining the therapeutic benefit of HAL treatment is discussed.
\end{abstract}

Key Words. Haloperidol, reduced haloperidol, plasma levels, Chinese, schizophrenia.

Haloperidol (HAL) is one of the most widely used neuroleptic medications for the treatment of psychiatric patients. The metabolism of HAL involves the oxidative dealkylation of the $\mathrm{C}-\mathrm{N}$ bond of the central chain to form inactive piperidine and 4-fluorobenzoylpropionic acid metabolites (Forsman et al., 1977). HAL is also metabolized via reduction at the benzylic ketone to form an alcohol metabolite, known as reduced HAL (RHAL) (Forsman and Larsson, 1978). The reduction of HAL has recently been demonstrated with ketone reductase that exists in human liver cytosol and red blood cells (Inaba and Kovacs, 1989; Inaba et al., 1989). After a

An earlier version of this report was presented at the 17th Collegium Internationale Neuropsychopharmacologium Congress, September 10-14, 1990, Kyoto, Japan.

Wen-Ho Chang, M.D., is Chief, Laboratory of Biological Psychiatry, and Hsien-Yuan Lane, M.D., Shih-Ku Lin, M.D., and Teng-Yi Chen, M.D., are Staff Psychiatrists, Department of Adult Psychiatry, Taipei City Psychiatric Center; Hai-Gwo Hwu, M.D., is Associate Professor, and Hsin-Nan Lin, M.D., is Professor, Department of Psychiatry, Medical College, National Taiwan University; Horng Chen, M.D., and Hae-Lang Wei, M.D., are Staff Psychiatrists, and Wen-Long Lin, M.D., is Director, Military 818 Psychiatric Hospital, Taipei, Taiwan, Republic of China. (Reprint requests to Dr. W.-H. Chang, Taipei City Psychiatric Center, 309 Sung-Te Road, Taipei, Taiwan 10510, ROC.)

0165-1781/91/\$03.50 1991 Elsevier Scientific Publishers Ireland Ltd. 
single dose administration, about $23 \%$ of the biotransformation of HAL is through the reduction pathway (Jann et al., 1990). Concentrations of RHAL have been found to be equal to or higher than those of the parent drug in blood and post-mortem brain tissue of HAL-treated patients (Forsman and Larsson, 1978; Korpi et al., 1984a). However, great interindividual variation of reductive drug-metabolizing activities has been observed in psychiatric patients (Ereshefsky et al., 1984; Chang et al. 1987a, 1991; Shostak et al., 1987; Altamura et al., 1988; Ko et al., 1989; Someya et al., 1990).

Studies of the relationship between plasma HAL level and clinical response in schizophrenic patients have yielded variable results (Volavka and Cooper, 1987). Several investigators have suggested that the inconsistent findings are at least partially due to the failure to assess RHAL levels (Ereshefsky et al., 1984; Chang et al. 1987a, 1991; Shostak et al., 1987; Altamura et al., 1988). The importance of the investigation of RHAL in biological samples may be that the reduced metabolite can be reconverted back to the parent drug (Korpi and Wyatt, 1984) and is about 1/5-1/2 as potent as HAL in some biochemical tests (Hays et al., 1980; Chang et al., $1987 b, 1987 c, 1988)$. RHAL itself, however, is probably an inactive drug or a very weak neuroleptic. It is devoid of neuroleptic effects in electrophysiologic studies after direct RHAL injection into dopaminergic neurons (Kirch et al., 1985b), and has a much weaker ability than HAL (1/85-1/400) to displace labeled ligands from dopamine receptors in vitro (Korpi and Wyatt, 1984; Bowen et al., 1990). Furthermore, elevated RHAL/HAL ratios are reportedly associated with a poor clinical response (Ereshefsky et al., 1984; Altamura et al., 1988; Ko et al., 1989), and it is hypothesized that high concentrations of RHAL in brain tissue can compete with HAL at receptor sites, thus reducing the effectiveness of HAL treatment (Korpi et al., 1985; Chang et al., 1991). In this study, we report the dose-dependent RHAL/HAL ratios in 113 HAL-treated Chinese schizophrenic patients.

\section{Methods}

Between April 1986 and March 1989, 113 Chinese inpatients ( 77 males, 36 females; mean age $=30.7$ years, $S D=9.8$, range $=16-60)$ participated in this study. The patients met $D S M-I I I$ criteria for schizophrenia (American Psychiatric Association, 1980) and were of normal weight $($ mean $=55.8 \mathrm{~kg}, \mathrm{SD}=8.0$, range $=40.0-82.0 \mathrm{~kg}$ ). The patients were hospitalized at the Taipei City Psychiatric Center, the National Taiwan University Hospital, and the Military 818 Psychiatric Hospital. All were physically healthy and had all laboratory parameters within normal limits. Patients were selected for analysis on the basis of the following parameters: stable HAL dosage for a minimum of 7 days; no enzyme-inducing agents (e.g., phenobarbital) or inhibiting drugs (e.g., cimetidine); nonsmokers or persons who smoked less than one pack per day of cigarettes; no oral or injectable HAL administered PRN 48 hours before blood sampling; and steady-state plasma HAL and RHAL concentrations measured at each dose. In all, 313 blood samples were collected. In some patients $(n=63)$, samples were obtained weekly for 2 to 6 times (mean $=3.3$ ) at the same dose level. The plasma drug levels in these patients were averaged and used for the analysis. In 31 of 113 patients, plasma samples were obtained on two or three different steady-state HAL dosages. In thoses cases, only the plasma drug concentrations obtained at the highest dose were selected for the interindividual analysis. From the total data set $(n=113)$, an intraindividual analysis was conducted to compare HAL and RHAL plasma concentrations in patients who had variable daily doses.

HAL (Haldol) was purchased from Janssen Pharmaceuticals, Beerse, Belgium. Daily doses 
ranging from 8 to $65 \mathrm{mg}$ were individually titrated according to clinical response. The only concurrent medications allowed were trihexyphenidyl and nitrazepam. Clinical assessments made by clinicians were based on patient interviews and nursing notes without use of a standardized rating scale. The incidence of extrapyramidal side effects could not be accurately determined due to the prophylactic use of anticholinergic medications in some paticnts. Therefore, data analysis was not attempted for clinical response and adverse effects.

Blood samples were obtained 10-12 hours after the evening dose and before the morning dose. Antecubital venous blood was collected into an EDTA-tube and centrifuged at 3,000 $\mathrm{rpm}$ for $15 \mathrm{~min}$. Plasma samples were stored at $-60^{\circ} \mathrm{C}$ until assayed. HAL and RHAL concentrations were measured by high performance liquid chromatography with electrochemical detection as described in detail by Korpi et al. (1983) with minor modifications (Chang et al., 1989). The minimum level of sensitivity was $0.4 \mathrm{ng} / \mathrm{ml}$ with intra-assay and interassay coefficients of variation from $4 \%$ to $12 \%$ for HAL and RHAL at $2-10 \mathrm{ng} / \mathrm{ml}$.

Statistical analysis was carried out using linear regression analysis with Pearson productmoment correlation coefficient and Student's $t$ test. A $p$ value $<0.05$ was considered statistically significant. Results are reported as mean $\pm \mathrm{SD}$.

\section{Results}

As shown in Fig. 1, the plasma HAL levels and dosages were highly correlated. The correlation coefficients were $0.85(p<0.0001)$ in $\mathrm{mg} /$ day and $0.84(p<0.0001)$ in $\mathrm{mg} / \mathrm{kg} /$ day with the equations of HAL plasma level $(\mathrm{ng} / \mathrm{ml})=0.88 \times$ dosage $(\mathrm{mg} /$ day $)-0.56$ and HAL plasma level $(\mathrm{ng} / \mathrm{ml})=46.0 \times$ dosage $(\mathrm{mg} /$ day $/ \mathrm{kg})$ +0.28 , respectively, as calculated from linear regression analysis.

Fig. 1. Correlation of haloperidol dosage ( $\mathrm{mg} /$ day, left and $\mathrm{mg} / \mathrm{kg} / \mathrm{day}$, right) and plasma level $(\mathbf{n g} / \mathrm{ml})$ in 113 patients
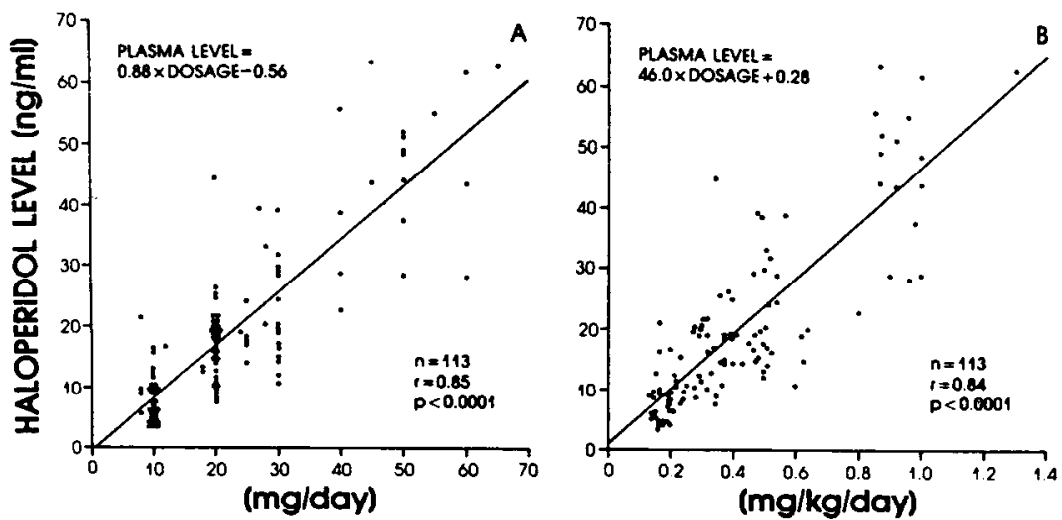

HALOPERIDOL DOSAGE

These two correlation coefficients had almost the same value, suggesting that body weight in the normal range may not be an important factor in the determination of plasma HAL level. However, the interpatient variation in plasma HAL levels at the same dose was wide. For example, the highest level $(44.3 \mathrm{ng} / \mathrm{ml})$ was almost six times the lowest level $(7.6 \mathrm{ng} / \mathrm{ml})$ in 34 patients who were administered the same daily dose of $20 \mathrm{mg} \mathrm{HAL}$ (Fig. 1A).

Fig. 2 plots the relationships between HAL and RHAL plasma levels. Upon 
Fig. 2. Correlation of plasma haloperidol level $(\mathrm{ng} / \mathrm{ml})$ and reduced haloperidol level $(\mathrm{ng} / \mathrm{ml})$ in 113 patients

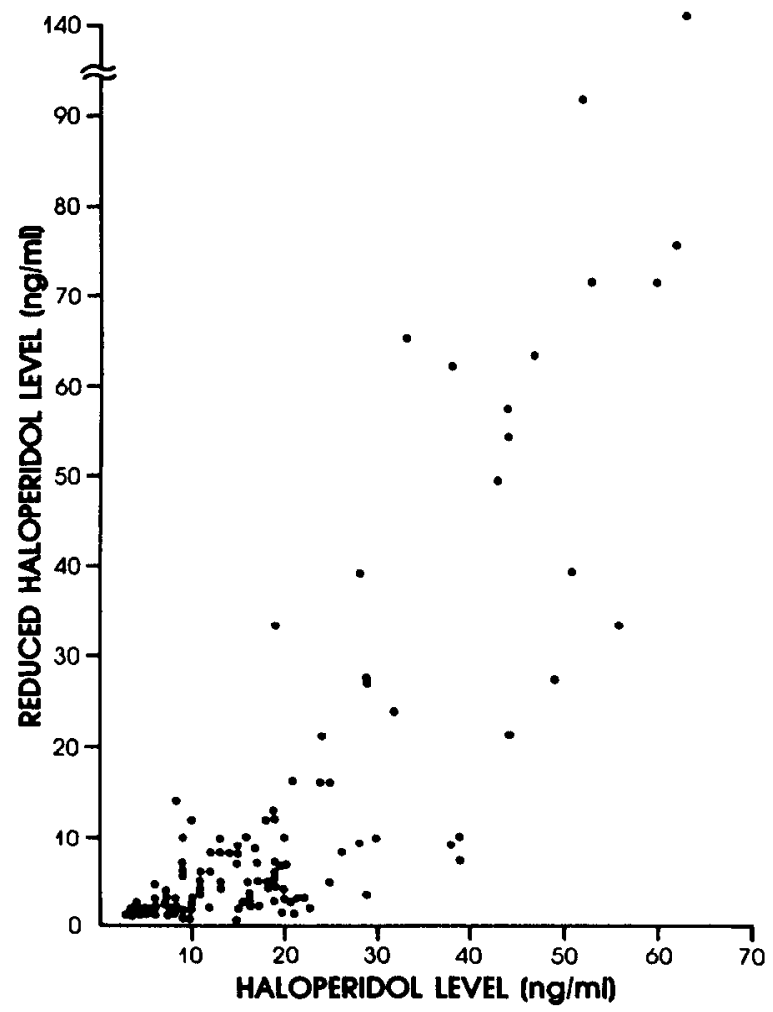

inspection of the graphic plots, a nonlinear relationship was found. When HAL levels were $<25 \mathrm{ng} / \mathrm{ml}$ (equivalent to $30 \mathrm{mg} /$ day from the above equation) $(n=86)$, RHAL levels were $<15 \mathrm{ng} / \mathrm{ml}$ for most patients $(n=82)$. Once HAL levels exceeded $25 \mathrm{ng} / \mathrm{ml}(n=27)$, however, RHAL levels increased at a much more rapid rate than HAL levels (about 3 times) (Table 1).

The interindividual relationship between plasma $\mathrm{RHAL} / \mathrm{HAL}$ ratio and HAL daily dosage in 113 patients also revealed a positive correlation (Fig. 3). However, the correlation coefficient, 0.62 , was at the medium level. Fig. 3 reveals very wide interpatient variation. For instance, the highest ratio (0.61) was 12 times the lowest ratio $(0.05)$ at a modest dose of $0.4 \mathrm{mg} / \mathrm{kg} /$ day. On the other hand, the dosedependent increase in the ratios was somewhat nonlinear. The ratios were increased much more rapidly when HAL dosage exceeded $0.54 \mathrm{mg} / \mathrm{kg} /$ day $(30 \mathrm{mg} /$ day for average body weight).

Moreover, this large data set was divided into six dose range groups (mg/day): 8-12, 18-25, 27-30, 40-45, 50, and 55-65 (Table 2). The dose-dependent RHAL/HAL ratios can be easily seen from these results (Table 2). In two groups of patients with daily dosages below $25 \mathrm{mg}$, the plasma concentrations of HAL were almost 3 times those 
Table 1. Plasma concentrations of haloperidol (HAL) and reduced haloperidol (RHAL) In 113 patients (mean \pm SD)

\begin{tabular}{|c|c|c|c|}
\hline & \multicolumn{2}{|c|}{ HAL level } & \multirow[b]{2}{*}{$\begin{array}{c}\text { Increase } \\
\text { (fold) } \\
{[(\mathbf{b}-\mathbf{a}) / \mathbf{a}]}\end{array}$} \\
\hline & $\begin{array}{c}<25 \mathrm{ng} / \mathrm{ml} \\
(n=86) \\
{[\mathrm{a}]}\end{array}$ & $\begin{array}{c}>25 \mathrm{ng} / \mathrm{ml} \\
(n=27) \\
{[b]}\end{array}$ & \\
\hline HAL level (ng/ml) & $13.5 \pm 5.8$ & $41.4 \pm 12.0$ & 2.1 \\
\hline RHAL level (ng/ml) & $5.3 \pm 4.9$ & $40.3 \pm 31.9$ & 6.6 \\
\hline RHAL/HAL ratio & $0.4 \pm 0.28$ & $0.92 \pm 0.59$ & 1.3 \\
\hline
\end{tabular}

of RHAL, with RHAL/ HAL ratios of 0.38 $\pm 0.24(8-12 \mathrm{mg})$ and $0.36 \pm 0.24(18-25$ $\mathrm{mg}$ ), respectively. When daily dosages increased to $30-45 \mathrm{mg}$, the ratios were almost double those of the two lower dose groups $(0.64 \pm 0.50$ for the $27-30 \mathrm{mg}$ group and $0.65 \pm 0.44$ for the $40-45 \mathrm{mg}$ group). The RHAL levels and RHAL/HAL ratios became more rapidly elevated when daily dosages exceeded $50 \mathrm{mg}$. The ratios of 50 $\mathrm{mg}$ and $55-65 \mathrm{mg}$ groups were $1.11 \pm 0.57$ and $1.45 \pm 0.44$, respectively. The ratios increased by factors of $1.71(1.11 / 0.65)$ and $2.23(1.45 / 0.65)$, respectively.

Fig. 3. Correlation of haloperidol dosage $(\mathrm{mg} / \mathrm{kg} / \mathrm{day})$ and plasma reduced haloperidol/haloperidol ratio in 113 patients

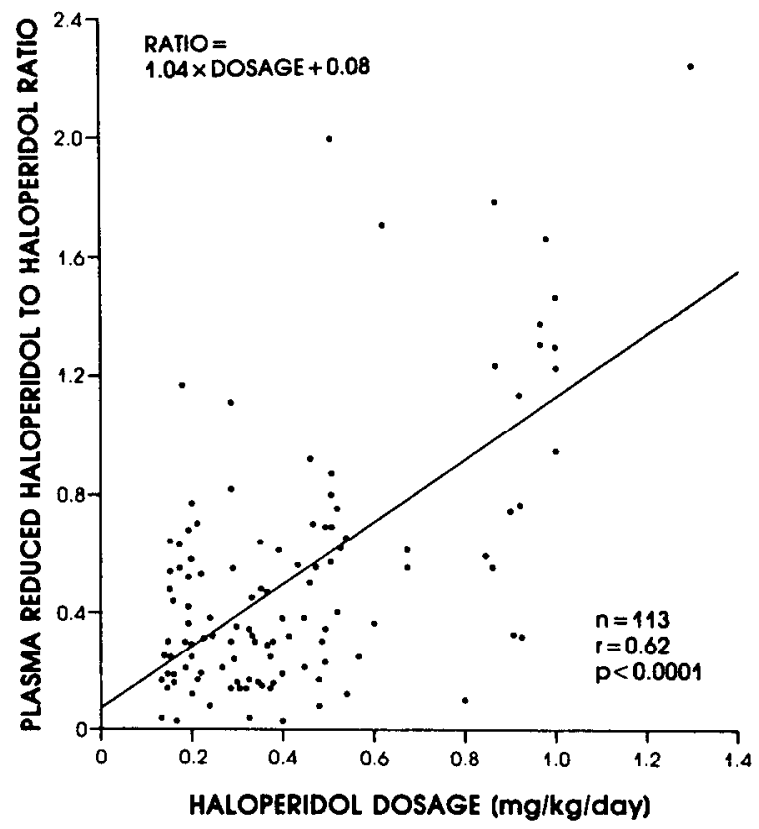

The dose-dependent increase in the RHAL/HAL ratios also existed in the intraindividual data (Table 3). After administration of $20-30 \mathrm{mg} /$ day and 40-60 
Table 2. Plasma concentrations of haloperidol (HAL) and reduced HAL (RHAL) and ratios of RHAL/HAL in 6 dose level groups

\begin{tabular}{|c|c|c|c|c|c|}
\hline \multicolumn{2}{|c|}{ Daily dose (mg) } & \multirow[b]{2}{*}{$n$} & \multicolumn{2}{|c|}{ Plasma level (ng/ml) } & \multirow{2}{*}{$\begin{array}{c}\text { RHAL/HAL } \\
\text { ratio }\end{array}$} \\
\hline Range & Mean \pm SD & & HAL & RHAL & \\
\hline $8-12$ & $9.8 \pm 0.8$ & 35 & $8.5 \pm 4.2$ & $3.0 \pm 2.4$ & $0.38 \pm 0.24$ \\
\hline $18-25$ & $20.6 \pm 1.8$ & 42 & $17.5 \pm 6.3$ & $6.3 \pm 4.8$ & $0.36 \pm 0.24$ \\
\hline $27-30$ & $29.6 \pm 0.9$ & 18 & $23.2 \pm 8.8$ & $14.9 \pm 15.0$ & $0.64 \pm 0.50$ \\
\hline $40-45$ & $41.7 \pm 2.6$ & 6 & $42.2 \pm 5.5$ & $29.1 \pm 20.9$ & $0.65 \pm 0.44$ \\
\hline 50 & 50.0 & 7 & $44.3 \pm 8.6$ & $50.4 \pm 27.8$ & $1.11 \pm 0.57$ \\
\hline $55-65$ & $60.0 \pm 3.5$ & 5 & $50.2 \pm 14.6$ & $74.7 \pm 39.3$ & $1.45 \pm 0.44$ \\
\hline
\end{tabular}

$\mathrm{mg} /$ day dosages at different stages, all patients, with one exception ( $\# 2)$, had elevated ratios when the dosages increased. The mean ratios increased from $0.67 \pm$ 0.34 of low dosages to $1.04 \pm 0.47$ of high dosages $(p<0.005)$. However, the interpatient variability was wide (-23-317\%). Two patients (\#1 and \#9) displayed a drastic elevation (threefold) in the ratios. One of them (\#9) showed a triple increase in RHAL level $(13.8 \mathrm{ng} / \mathrm{ml}$ vs. $38.6 \mathrm{ng} / \mathrm{ml})$, but no increase in HAL level $(30.4 \mathrm{ng} / \mathrm{ml}$ vs. $28.1 \mathrm{ng} / \mathrm{ml}$ ), when the dose increased from $30 \mathrm{mg} /$ day to $60 \mathrm{mg} /$ day. Significant intraindividual differences of RHAL/HAL ratios were not found between 10 $\mathrm{mg} /$ day vs. $20 \mathrm{mg} /$ day and $20 \mathrm{mg} /$ day vs. $30 \mathrm{mg} /$ day (data not shown).

Table 3. Steady state plasma levels of haloperidol (HAL) and reduced HAL (RHAL) in patients treated with different doses of HAL

\begin{tabular}{|c|c|c|c|c|c|c|c|c|}
\hline \multirow[b]{2}{*}{$\begin{array}{l}\text { Patient } \\
\# \\
\end{array}$} & \multicolumn{4}{|c|}{ Low dose } & \multicolumn{4}{|c|}{ High dose } \\
\hline & $\begin{array}{l}\text { Dose } \\
\text { (mg/ } \\
\text { day) }\end{array}$ & $\begin{array}{l}\text { HAL } \\
\text { (ng/ } \\
\text { ml) }\end{array}$ & $\begin{array}{c}\text { RHAL } \\
\text { (ng/ } \\
\mathrm{ml})\end{array}$ & $\begin{array}{c}\text { RHAL/ } \\
\text { HAL } \\
\text { ratio }\end{array}$ & $\begin{array}{l}\text { Dose } \\
\text { (mg/ } \\
\text { day) }\end{array}$ & $\begin{array}{c}\text { HAL } \\
\text { (ng/ } \\
\mathrm{ml})\end{array}$ & $\begin{array}{c}\text { PHAL } \\
\text { (ng/ } \\
\mathbf{m l})\end{array}$ & $\begin{array}{c}\text { RHAL/ } \\
\text { HAL } \\
\text { ratio }\end{array}$ \\
\hline 1 & 25 & 16.6 & 7.7 & 0.46 & 50 & 48.4 & 70.6 & 1.46 \\
\hline 2 & 25 & 18.8 & 15.2 & 0.81 & 50 & 49.0 & 30.3 & 0.62 \\
\hline 3 & 30 & 21.2 & 18.5 & 0.87 & 55 & 55.0 & 71.3 & 1.30 \\
\hline 4 & 25 & 40.6 & 15.0 & 0.37 & 45 & 63.4 & 46.6 & 0.74 \\
\hline 5 & 25 & 33.2 & 39.0 & 1.18 & 50 & 52.0 & 91.4 & 1.76 \\
\hline 6 & 25 & 29.4 & 32.0 & 1.09 & 50 & 43.9 & 53.9 & 1.23 \\
\hline 7 & 30 & 23.6 & 19.9 & 0.84 & 60 & 61.7 & 75.0 & 1.22 \\
\hline 8 & 25 & 24.8 & 17.0 & 0.69 & 45 & 43.8 & 56.5 & 1.29 \\
\hline 9 & 30 & 30.4 & 13.8 & 0.45 & 60 & 28.1 & 38.6 & 1.37 \\
\hline 10 & 25 & 16.8 & 9.4 & 0.56 & 50 & 51.0 & 38.9 & 0.76 \\
\hline 11 & 25 & 18.7 & 24.3 & 1.30 & 50 & 37.5 & 61.8 & 1.65 \\
\hline 12 & 25 & 16.3 & 5.0 & 0.31 & 50 & 28.4 & 9.0 & 0.32 \\
\hline 13 & 20 & 18.6 & 10.4 & 0.56 & 40 & 26.2 & 25.8 & 0.96 \\
\hline 14 & 20 & 34.9 & 12.3 & 0.35 & 40 & 55.7 & 32.6 & 0.59 \\
\hline 15 & 30 & 23.0 & 3.9 & 0.17 & 40 & 38.7 & 9.7 & 0.25 \\
\hline Mean & 25.7 & 24.5 & 16.2 & 0.67 & 49.0 & 45.5 & 47.5 & 1.04 \\
\hline SD & 3.2 & 7.6 & 9.7 & 0.34 & 6.3 & 11.8 & 24.1 & 0.47 \\
\hline
\end{tabular}




\section{Discussion}

Of the many neuroleptic medications whose plasma concentrations can be measured, the monitoring of HAL levels has been investigated most intensively and suggested to be a useful approach in clinical pharmacology (Dahl, 1986). In agreement with several previous investigations (Forsman et al., 1974; Calil et al., 1979; Penny et al., 1979; Bjorndal et al., 1980; Dunlop et al., 1982; Hollister and Kim, 1982; Moulin et al., 1982; Someya et al., 1990), a highly significant positive correlation between dose and plasma level of HAL was found in the present study, though the interpatient variation in plasma levels was wide.

On the basis of the equation of HAL plasma level $(\mathrm{ng} / \mathrm{ml})=0.88 \times$ dosage $(\mathrm{mg} / \mathrm{day})-0.56$ or $46.0 \times$ dosage $(\mathrm{mg} / \mathrm{day} / \mathrm{kg})+0.28$, the steady-state plasma level was calculated to be $8.2 \mathrm{ng} / \mathrm{ml}$ or $8.6 \mathrm{ng} / \mathrm{ml}$ in patients who were administered $\mathrm{HAL}$ $10 \mathrm{mg} /$ day or $0.18 \mathrm{mg} / \mathrm{kg} /$ day for those with an average body weight $(55.8 \mathrm{~kg})$. An approximate rule that each $1 \mathrm{mg} /$ day $\mathrm{HAL}$ orally results in $1 \mathrm{ng} / \mathrm{ml}$ of plasma HAL was roughly borne out. These values are about $15-55 \%$ higher than the concentrations of $6.3 \mathrm{ng} / \mathrm{ml}$ observed in Japanese patients (Someya et al., 1990) and of 5.4 $\mathrm{ng} / \mathrm{ml}$ (Forsman et al., 1974), $5.7 \mathrm{ng} / \mathrm{ml}$ (Penny ct al., 1979), 6.1-7.3 ng/ml (Moulin et al., 1982), $6.4 \mathrm{ng} / \mathrm{ml}$ (Miller et al., 1990), and $7.0 \mathrm{ng} / \mathrm{ml}$ (Shostak et al., 1987) in Caucasians. One possibility for this difference might be explained by the findings of trans-ethnic pharmacology investigations (Potkin et al., 1984; Chang et al., 1987a, 1990; Lin et al., 1988; Jann et al., 1989). For example, Potkin et al. (1984) reported that Chinese patients had a 52\% higher serum HAL level than Caucasian and Negro patients treated with a fixed dose.

In many of the previous studies, RHAL has not been measured and its clinical significance has not been evaluated. Investigations concerning the relationship between plasma RHAL level and clinical response have been conducted since 1984 (Ereshefsky et al., 1984; Chang et al., 1987a; Shostak et al., 1987; Altamura et al., 1988; Ko et al., 1989). Several investigators have reported that high RHAL/HAL ratios are related to poor clinical response in psychiatric patients (Ereshefsky et al., 1984; Altamura et al., 1988; Ko et al., 1989), though the evidence for such a correlation is very tentative. An explanation for this phenomenon might be that a high RHAL concentration could reduce the effectiveness of HAL treatment, as suggested by Korpi et al. (1985) and Chang et al. (1991).

In agreement with the investigations of Browning et al. (1985), Ereshefsky et al. (1986), and Someya et al. (1990), a nonlinear relationship between HAL and RHAL plasma concentrations or a dose-dependent increase in the ratios of RHAL/HAL was revealed in this study. This phenomenon could reflect a saturating process in the disposition of HAL and RHAL, and might be related to the interconversion step (reduction/oxidation circle) or directly caused by RHAL metabolism as RHAL was conjugated with glucuronide, but HAL was not, in enterohepatic recirculation (Eddington and Young, 1990) (Fig. 4). A sparteine test conducted by Gram et al. (1989) indicated that a therapeutic dose of HAL inhibits the activity of sparteine oxygenase and causes a marked increase in the sparteine metabolic ratio. This inhibition of the oxidative enzyme system induced by HAL per se might also be one 
Fig. 4. Metabolism of haloperidol

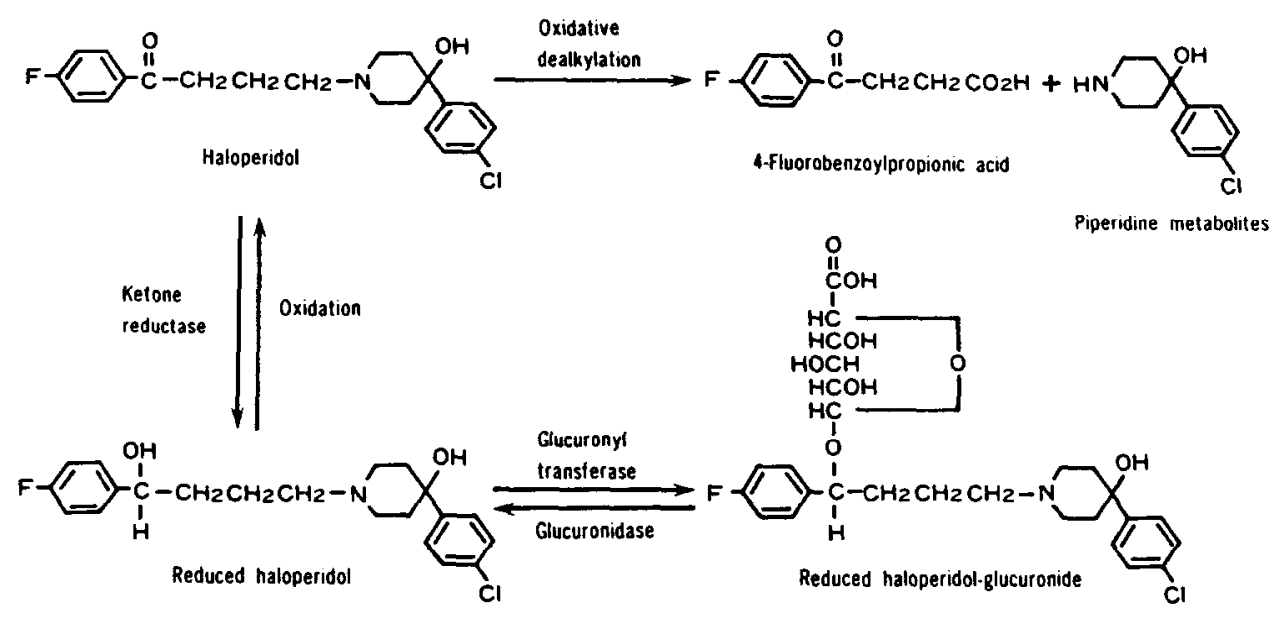

reason why high RHAL levels or RHAL/HAL ratios are observed following high dose HAL administrations.

As can be seen in Fig. 3, the interpatient variation in the ratios was also wide, even at the same dosage. However, there was no clear trend toward a bimodal distribution of RHAL/HAL ratios, as suggested by Someya et al. (1990), if the dose factor was controlled. At least two major sources could contribute to variable plasma RHAL/HAL ratios. The reduction/oxidation cycle in the interconversion between HAL and RHAL could be one of the major sources for interpatient variation in RHAL/HAL ratio. The enzymes involved in this interconversion process may differ among populations. In a preliminary study, however, Shibasaki et al. (1990) have not found any significant correlation between HAL reductase activities in the red blood cells and RHAL/HAL ratios in plasma in 14 Oriental patients. In the guinea pig, RHAL was reported to be conjugated with glucuronide in biliary recycling. RHAL-glucuronide can also be hydrolyzed back to RHAL (Eddington and Young, 1990). Interpatient variation in the conjugation/hydrolysis process could also be great.

On the basis of the nonlinear increase in RHAL levels, the upper therapeutic limit of $25 \mathrm{ng} / \mathrm{ml}$ HAL level suggested by several investigators (Kirch et al., 1985a; Potkin et al., 1985; Dahl, 1986; Volavka and Cooper, 1987) is reasonable, because a drastic elevation in RHAL levels occurred when HAL levels exceeded $25 \mathrm{ng} / \mathrm{ml}$. Dosing information for HAL can be also inferred from this finding. If most investigators agree that the upper therapeutic limit or plateau for HAL plasma concentration is not higher than $25 \mathrm{ng} / \mathrm{ml}$ (Kirch et al., 1985a; Potkin et al., 1985; Dahl, 1986; Volavka and Cooper, 1987), dosages $>30 \mathrm{mg} /$ day would not be necessary for most Chinese patients. This dosage is somewhat smaller than the suggested criterion of 40 $\mathrm{mg} /$ day for Caucasian patients (Shostak et al., 1987).

If the suggestion that high ratios of $\mathrm{RHAL} / \mathrm{HAL}$ or high concentrations of RHAL are linked to poor clinical response can be replicated by further 
investigations, a hypothesis concerning therapeutic window effect (if it exists) of HAL treatment could be made. During HAL treatment with high doses (e.g., $\geqslant 50$ $\mathrm{mg} /$ day), RHAL could accumulate in the brain tissue in high concentrations ( RHAL $/$ HAL $>1.0$ ). Because the reduction process only results in a minor change in the molecular structure, RHAL, as a "false neuroleptic" or "false blocker," could compete with the parent drug at dopamine $D_{2}$ receptors (Korpi and Wyatt, 1984; Korpi et al., 1984b; Bowen et al., 1990), but not block dopamine transmission (Kirch et al., 1985b). Consequently, RHAL could interfere with the pharmacologic activity of HAL at receptor sites, and diminish the neuroleptic effects of the parent drug. On the other hand, once the dosage of $\mathrm{HAL}$ was decreased, the reduced metabolite, as a precursor of $\mathrm{HAL}$, could be reconverted back to the active drug with neuroleptic properties, thus reducing the competitive effect of RHAL on HAL at dopamine $D_{2}$ receptors. It is possible that lower levels of RHAL (RHAL/HAL $\leqslant 1.0)$ in patients treated with a modest dose of $\mathrm{HAL}(<30 \mathrm{mg} /$ day) could result in the drug being more biologically active at the rcceptor sites.

Acknowledgments. The authors thank Markku Linnoila, M.D., Ph.D., for his comments on an earlier version of this manuscript, and Shu-Swei Jaw and Ho-Sheng Wu for technical assistance. This work was supported by grants NSC78-0412-B109-01 and NSC79-0412-B10901 from the National Science Council and Taipei City Government.

\section{References}

Altamura, C.; Mauri, M.; Cavallaro, R.; Colacurcio, F.; Gorni, A.; and Bareggi, S. Reduced haloperidol/haloperidol ratio and clinical outcomes in schizophrenia: Preliminary evidence. Progress in Neuro-Psychopharmacology and Biological Psychiatry, 12:689-694, 1988.

American Psychiatric Association. DSM-III: Diagnosis and Statistical Manual of Mental Disorders. 3rd ed. Washington, DC: Author, 1980. pp. 181-193.

Bjorndal, N.; Bjerre, N.; Gerlach, J.; Kristjansen, P.; Magelund, G.; Oestrich, I.H.; and Wahrens, J. High dosage haloperidol therapy in chronic schizophrenic patients: A doubleblind study of clinical response, side effects, serum haloperidol and serum prolactin. Psychopharmacology, 67:17-23, 1980.

Bowen, W.D.; Moses, E.L.; Tolentino, P.J.; and Walker, J.M. Metabolites of haloperidol display preferential activity at $\sigma$-receptors compared to dopamine $\mathrm{D}_{2}$ receptors. European Journal of Pharmacology, 177:111-118, 1990.

Browning, J.L.; Harrington, C.A.; and Davis, C.M. Quantification of reduced haloperidol and haloperidol by radioimmunoassay. Journal of Immunoassay, 6:45-66, 1985.

Calil, H.M.; Avery, D.H.; Hollister, L.E.; Creese, I.; and Snyder, S.H. Serum levels of neuroleptics measured by dopamine radioreceptor assay and some clinical observations. Psychiatry Research, 1:39-44, 1979.

Chang, W.H.; Chen, T.Y.; Lee, C.F.; Hu, W.H.; and Yeh, E.K. Low plasma reduced haloperidol/haloperidol ratios in Chinese patients. Biological Psychiatry, 22:1406-1408, $1987 a$.

Chang, W.H.; Chen, T.Y.; and Yeh, E.K. Time-response curves of homovanillic acid in caudate and pre-frontal cortex following acute neuroleptic administration. Psychopharmacology, 93:403-404, $1987 b$.

Chang, W.H.; Jann, M.W.; Hwu, H.G.; Chen, T.Y.; Yeh, E.K.; Chien, C.P.; Ereshefsky, L.; Saklad, S.R.; and Richard, A.L. Ethnic comparison of haloperidol and reduced haloperidol plasma levels: Chinese versus non-Chinese. Clinical Neuropharmacology, 13(Suppl. 2):538$539,1990$. 
Chang, W.H.; Jaw, S.S.; Wu, S.H.; Tsay, L.; and Yeh, E.K. Pharmacodynamics and pharmacokinetics of haloperidol and reduced haloperidol in guinea pigs. Psychopharmacology, 96:285-288, 1988.

Chang, W.H.; Lin, S.K.; and Jann, M.W. Interconversions between haloperidol and reduced haloperidol in schizophrenic patients and guinea pigs: A steady state study. Journal of Clinical Psychopharmacology, 11:99-105, 1991.

Chang, W.H.; Lin, S.K.; Jann, M.W.; Lam, Y.W.F.; Chen, T.Y.; Chen, C.T.; Hu, W.H.; and Yeh, E.K. Pharmacodynamics and pharmacokinetics of haloperidol and reduced haloperidol in schizophrenic patients. Biological Psychiatry, 26:239-249, 1989.

Chang, W.H.; Wu, H.S.; and Tseng, Y.T. Reduced haloperidol and haloperidol: Effects on homovanillic acid in caudate and pre-frontal cortex. Biological Psychiatry, 22:1369-1374, $1987 c$.

Dahl, S.G. Plasma level monitoring of antipsychotic drugs: Clinical utility. Clinical Pharmacokinetics, 11:36-61, 1986.

Dunlop, S.R.; Shea, P.A.; and Hendrie, H.C. The relationship between plasma and red blood cell neuroleptic levels, oral dosage, and clinical parameters in chronic schizophrenic population. Biological Psychiatry, 17:929-936, 1982.

Eddington, N.D., and Young, D.L. Biliary excretion of reduced haloperidol glucuronide. Psychopharmacology, 100:46-48, 1990.

Ereshefsky, L.; Davis, C.M.; Harrington, C.A.; Jann, M.W.; Browning, J.L.; Saklad, S.R.; and Burch, N.R. Haloperidol and reduced haloperidol plasma levels in selected schizophrenic patients. Journal of Clinical Psychopharmacology, 4:138-142, 1984.

Ereshefsky, L.; Jann, M.W.; Saklad, S.R.; and Davis, C.M. Bioavailability of psychotropic drugs: Historical perspective and pharmacokinetic overview. Journal of Clinical Psychiatry, 47(Suppl. 9):6-15, 1986.

Forsman, A.; Folsch, G.; Larsson, M.; and Ohman, R. On the metabolism of haloperidol in man. Current Therapeutic Research, 21:606-617, 1977.

Forsman, A., and Larsson, M. Metabolism of haloperidol. Current Therapeutic Research, 24:567-568, 1978.

Forsman, A.; Martensson, E.; Nyberg, G.; and Ohman, R. A gas chromatographic method for determining haloperidol: A sensitive procedure for studying serum concentration and pharmacokinetics of haloperidol in patients. Naunyn-Schmiedeberg's Archives of Pharmacology, 286:113-124, 1974.

Gram, L.F.; Debrutne, D.; Caillard, V.; Boulenger, J.P.; Lacotte, J.; Moulin, M.; and Zarifian, E. Substantial rise in spartine metabolic ratio during haloperidol treatment. British Journal of Clinical Pharmacology, 27:272-275, 1989.

Hays, S.E.; Poland, R.E.; and Rubin, R.T. Prolactin releasing potencies of antipsychotic and related nonantipsychotic compounds in female rats: Relation to clinical potencies. Journal of Pharmacology and Experimental Therapeutics, 214:362-367, 1980.

Hollister, L.E., and Kim, D.Y. Intensive treatment with haloperidol of treatment-resistant chronic schizophrenic patients. American Journal of Psychiatry, 139:1466-1468, 1982.

Inaba, T.; Kalow, W.; Someya, T.; Takahashi, S.; Cheung, S.W.; and Tang, S.W. Haloperidol reduction can be assayed in human red blood cells. Canadian Journal of Physiology and Pharmacology, 67:1468-1469, 1989.

Inaba, T., and Kovacs, J. Haloperidol reductase in human and guinea pig livers. Drug Metabolism and Disposition, 17:330-333, 1989.

Jann, M.W.; Chang, W.H.; Davis, C.M.; Chen, T.Y.; Deng, H.C.; Lung, F.W.; Ereshefsky, L.; Saklad, S.R.; and Richards, A.L. Haloperidol and reduced haloperidol plasma levels in Chinese and non-Chinese psychiatric patients. Psychiatry Research, 30:45-52, 1989.

Jann, M.W.; Lam, F.Y.W.; and Chang, W.H. Reversible metabolism of haloperidol and reduced haloperidol in Chinese schizophrenic patients. Psychopharmacology, 101:107-111, 1990.

Kirch, D.G.; Bigelow, L.B.; and Wyatt, R.J. The interpretation of plasma haloperidol concentrations. Archives of General Psychiatry, 42:838-839, $1985 a$. 
Kirch, D.G.; Plamer, M.R.; and Egan M. Electrophysiological interactions between haloperidol and reduced haloperidol, and dopamine, norepinephrine, and phencycline in rat brain. Neuropharmacology, 24:375-379, $1985 b$.

Ko, G.N.; Korpi, E.R.; and Kirch, D.G. Haloperidol and reduced haloperidol concentrations in plasma and red blood cells from chronic schizophrenic patients. Journal of Clinical Psychopharmacology, 9:186-190, 1989.

Korpi, E.R.; Costakos, D.T.; and Wyatt, R.J. Interconversions of haloperidol and reduced haloperidol in guinea pig and rat liver microsomes. Biochemical Pharmacology, 34:2923-2927, 1985.

Korpi, E.R.; Kleinman, J.E.; Costakos, D.T.; Linnoila, M.; and Wyatt, R.J. Reduced haloperidol in the post-mortem brains of haloperidol treated patients. Psychiatry Research, 11:259-269, 1984a.

Korpi, E.R.; Ko, G.N.; Phelps, B.H.; and Wyatt, R.J. Possible interference by the reduced haloperidol metabolite with the radioimmunoassay and radioreceptor assay of blood haloperidol. Journal of Clinical Psychopharmacology, 4:332-335, $1984 b$.

Korpi, E.R.; Phelps, B.; Granger, H.; Chang, W.H.; Linnoila, M.; Meek, J.L.; and Wyatt, R.J. Simultaneous determination of haloperidol and its reduced metabolite in serum and plasma by isocratic liquid chromatography with electrochemical detection. Clinical Chemistry, 29:624-628, 1983.

Korpi, E.R., and Wyatt, R.J. Reduced haloperidol: Effects on striatal dopamine metabolism and conversion to haloperidol in the rat. Psychopharmacology, 83:34-37, 1984.

Lin, K.M.; Poland, R.E.; Lau, J.K.; Rubin, R.T. Haloperidol and prolactin concentrations in Asians and Caucasians. Journal of Clinical Psychopharmacology, 8:195-198, 1988.

Miller, D.D.; Perry, P.J.; Kelly, M.W.; Coryell, W.H.; and Arndt, S.V. Pharmacokinetic protocol for predicting plasma haloperidol concentrations. Journal of Clinical Psychopharmacology, 10:207-212, 1990.

Moulin, M.A.; Davy, J.P.; Debruyne, D.; Anderson, J.C.; Bigot, M.C.; Camsonne, R.; and Poilpre, E. Serum level monitoring and therapeutic effect of haloperidol in schizophrenic patients. Psychopharmacology, 76:346-350, 1982.

Penny, J.E.; Evans, L.; Eadie, M.J.; and Tyrer, J.H. Plasma haloperidol levels in man during high-dosage therapy with the drug. Clinical Experimental Pharmacology and Physiology, 6:214, 1979.

Potkin, S.G.; Shen, Y.; Pardes, H.; Phelps, B.H.; Zhou, D.; Shu, L.; Korpi, E.R.; and Wyatt, R.J. Haloperidol concentrations elevated in Chinese patients. Psychiatry Research, 12:167-172, 1984.

Potkin, S.G.; Shen, Y.; Zhou, D.; Pardes, H.; Shu, L.; Phelps, B.; and Poland, R. Does a therapeutic window for plasma haloperidol exist? Preliminary Chinese data. Psychopharmacology Bulletin, 21:59-61, 1985.

Shibasaki, M.; Someya, T.; Kato, T.; Noguchi, T.; Ishida, N.; and Takahashi, S. Measurement of haloperidol reductase activity in red blood cells and reduced haloperidol/haloperidol ratios in plasma in Oriental psychiatric patients. Progress in NeuroPsychopharmacology and Biological Psychiatry, 14:941-947, 1990.

Shostak, M.; Perel, J.; Stiller, R.L.; Wyman, W.; and Curran, S. Plasma haloperidol and clinical response: A role for reduced haloperidol in antipsychotic activity? Journal of Clinical Psychopharmacology, 7:394-400, 1987.

Someya, T.; Takahashi, S.; Shibasaki, M.; Inaba, T.; Cheung, S.W.; and Tang, S.W. Reduced haloperidol/haloperidol ratios in plasma: Polymorphism in Japanese psychiatric patients. Psychiatry Research, 31:111-120, 1990.

Volavka, J., and Cooper, T.B. Review of haloperidol blood levels and clinical response: Looking through the window. Journal of Clinical Psychopharmacology, 7:25-30, 1987. 